\title{
STOP THE PRESS: WHY CENSORSHIP HAS MADE HEADLINE NEWS (AGAIN)
}

L Mills

\section{People demand freedom of speech as a compensation for the} freedom of thought which they seldom use.

Soren Kierkegaard (1813-1855)

\section{Introduction}

The recent publication of the proposed amendments ${ }^{1}$ to the Films and Publications Act $^{2}$ has drawn sharp reaction from various media organisations. Associations such as the South African National Editors' Forum (SANEF), the Media Institute of Southern Africa (MISA) and the Freedom of Expression Institute (FXI) have criticised the amendments as having the effect that -

...the media will be subjected to pre-publication censorship, probably forced to expunge large amounts of their news coverage from their pages or broadcasts and submit to procedures which will prevent papers from being distributed on a daily or weekly basis and result in broadcasters having to delay news broadcasts. ${ }^{3}$

Others have described the Bill as "part of a new trend in the gradual erosion of the freedom of speech" 4 and "not only outrageous and unconstitutional, [but also] ... unworkable". 5 The Department of Home Affairs (the government

* $\quad$ BA (Law) LLB LLM. Senior Lecturer, University of Stellenbosch. Chief Examiner: Film and Publication Board.

** Quotations 2007 http://www.quotationspage.com/ 20 Apr.

1 Films and Publications Amendment Bill, B27-2006.

2 Films and Publications Act 65 of 1996, as amended, hereafter the Act.

3 Joint statement on media censorship planned by government, see SANEF 2006 http://www.sanef.org.za/ 12 Nov.

4 Leon 2006 SA Today http://www.da.org.za/ 29 Aug.

5 Harber 2006 The Harbinger http://www.big.co.za/ 9 Nov. One of the comments posted on the site begs the question as to "[w]hy is this amendment introduced now, when the president is somehow implicated in the arms deal? This will prevent the freedom of press! I 
department responsible for the Act) have defended the amendments by stressing that the issue was how best to protect children from sexual exploitation in the media and thus attempting to -

...protect children from potentially disturbing, harmful or ageinappropriate materials. ${ }^{6}$

As it is not the duty of the State alone to protect children, it is time for the media to acknowledge that it too has an obligation towards society and that the protection of children is -

...no less important than the right of the press to publish any content that may be regarded by them to be in demand by their consumers. ${ }^{7}$

Cabinet has, in turn, reiterated that -

...the government has no intention whatsoever to muzzle the media in any way and that this position will not change. ${ }^{8}$

It often has been said that the media is a key agent in society in the protection of freedom of expression and that it "must foster it". ${ }^{9}$ This constitutional right, enshrined in section 16 of the Constitution, ${ }^{10}$ is formulated as follows:

(1) Everyone has the right to freedom of expression, which includes-

(a) freedom of the press and other media;

(b) freedom to receive or impart information or ideas;

(c) freedom of artistic creativity; and

(d) academic freedom and freedom of scientific research.

(2) The right in subsection (1) does not extend to-

hope it will be rightfully debated and failed in parliament or else our country is headed for doom!" Another describes the amendments as "an expensive, time wasting joke."

6 See the Department of Home Affairs Publication of Explanatory Summary of the Films and Publications Amendment Bill 2006, published in GG 29169 of 2006.

7 Gigaba 2006 Sunday Times 36.

8 Quintal 2006 Pretoria News http://www.iol.co.za/ 3 Nov.

$9 \quad$ Khumalo v Holomisa 2002 (5) SA 401 (CC) (2002 (8) BCLR 771) at par [22].

10 The Constitution of the Republic of South Africa 1996, hereinafter the Constitution. 
(a) propaganda for war;

(b) incitement of imminent violence; or

(c) advocacy of hatred that is based on race, ethnicity, gender or religion, and that constitutes incitement to cause harm.

Having regard to South Africa's recent past of censorship, secrecy and intellectual repression, any suggestion that the government is trying to reintroduce draconian forms of censorship legislation must be vehemently opposed. ${ }^{11}$ It is, therefore, important and thus the purpose of this discussion, to ascertain why these proposed amendments have been described as "outrageous and unconstitutional", whether it would cause a delay in publishing newspapers or broadcasting news reports or whether this is merely an overreaction by the various media institutions. After a brief synopsis of the history of censorship legislation in South Africa, this note will examine the classification process under the current Films and Publications Act. An analysis of some of the most controversial aspects of the Amendment Bill will follow, while paying particular attention to the response these have elicited from the media.

\section{Historical overview}

A brief historical review of obscenity law and censorship in South Africa provides a contextual basis for a consideration of the current Films and Publications Act, its purpose and the present reaction to the amendment thereof. ${ }^{12}$ Censorship legislation in South Africa dates back to colonial Acts

11 The importance of this right has been emphasised by the Constitutional Court on numerous occasions. See eg South African National Defence Union v Minister of Defence 1999 (4) SA 469 (CC) (1999 (6) BCLR 615) at par [7] where O'Regan j stated that "[f]reedom of expression is an important right in our Bill of Rights. It lies at the heart of a democracy. It is valuable for many reasons, including its instrumental function as a guarantor of democracy, its implicit recognition and protection of the moral agency of individuals in our society and its facilitation of the search for truth by individuals and society generally. The Constitution recognises that individuals in our society need to be able to hear, form and express opinions and views freely on a wide range of matters."

12 For a more comprehensive study of censorship in South Africa, see Merrettt Culture of Censorship. See also par [6]-[16] of Case v Minister of Safety and Security; Curtis $v$ 
such as the Cape of Good Hope Obscene Publications Act 31 of 1892. This $\mathrm{Act}^{13}$ prohibited the importation of indecent or obscene publications as well as the transmission of such matter through the mail. ${ }^{14}$ The Act did not create any enforcement body or authority, but provided for a Resident Magistrate, upon receiving a complaint "upon oath", to authorise any "constable or police officer to enter in the daytime" into any house, shop, room or "other place", using force to break open doors if necessary, "to search for and seize" all indecent and obscene publications found "and to carry all the articles so seized before the Resident Magistrate". ${ }^{15}$ Pre-Union cases established that the common-law crime of public indecency, defined as "conduct in public [which] of its very nature, must tend to the depravement of the morals of others," 16 may also exist in the publication of an indecent sketch. ${ }^{17}$

After Unification in 1910, the various colonial statutes were replaced by the Customs Management Act 9 of 1913. In 1931 the House of Assembly of the Union of South Africa enacted the Entertainments (Censorship) Act ${ }^{18}$ which established a "Board of Censors", appointed by the Minister of the Interior, to examine -

Minister of Safety and Security 1996 (3) SA 617 (CC) (1996 (1) SACR 587; 1996 (5) BCLR 609).

13 Read with s 14 of the Customs Act 10 of 1872, s 38 of the Customs Consolidation and Shipping Act 13 of 1899 and s 3 of the Customs Management Ordinance 23 of 1902.

14 S 7.

15 S 3

16 De Villiers cj in $R v$ Marais (1886) 6 SC 367 at 370.

$17 R v$ Bungaroo (1904) 25 NLR 28 at 29-30. In 1905 in $R v$ Hardy (1905) 26 NLR 165 a Natal Court convicted an editor responsible for an obscene newspaper report of public indecency. The newspaper published an article describing "immoral practices" between "native" men and "European" women. The court acknowledged at 170 that the offence was "not capable of very accurate definition" but applied a test derived from $R v$ Hicklin (1868) LR 3 QB 360 at 371 -also known as the Hicklin-test- of "whether the tendency of the matter ... is to deprave and corrupt those whose minds are open to such immoral influences, and into whose hands a publication of this sort may fall". The court furthermore noted at 171 that "(i)t would be impossible to deny that in the works of many writers of ancient times, as well as in those of standard authors of a later period, passages of an extremely indecent and obscene character are to be found, the publication of which in the newspaper press of the present day would be an offence against good morals amounting to public indecency."

18 Entertainments (Censorship) Act 28 of 1931. 
...films and film advertisements intended for public exhibition in any place in the Union. ${ }^{19}$

The Act furthermore provided that the Board shall not approve any film which, -

...in its opinion, depicts any matter that prejudicially affects the safety of the State, or is calculated to disturb peace or good order, or prejudice the general welfare or be offensive to decency. ${ }^{20}$

The Customs Act 35 of 1944 also prohibited the importation of any indecent or obscene goods or on any other ground whatsoever objectionable ${ }^{21}$ and subjected these goods to forfeiture.

Except to the extent to which the Customs Act provided for control over the importation of "undesirable publications and objects", there was no control over publications. To cure this lacuna, a public commission of enquiry ${ }^{22}$ was appointed in 1954 to -

...find ways and means of combating the evil of indecent, offensive or harmful literature.

Some of its recommendations included a Publications Board to register all publishers and booksellers, a single control system for imported and local publications and the suggestion that magazines should be sold only from official kiosks. ${ }^{23}$ It also recommended a legal definition of "undesirable" to embrace material seen as "indecent, offensive or harmful" by the "ordinary, civilised, decent, reasonable and responsible inhabitants of South Africa" and

$19 \mathrm{~S} 2$.

20 S 5(1). Such scenes or acts included impersonation of the King and ridicule of the military; death; nudity; passionate love scenes; controversial or international politics; antagonistic relations between capital and labour; pugilistic encounters; and scenes of intermingling between Europeans and non-Europeans. In 1953 the court in $R \vee W 1953$ (3) SA 52 (SWA) found a figurine of a naked boy urinating, an alleged reproduction of the famous street fountain in Brussels, to be indecent. The court held that it was very likely that South Africans would regard as indecent what the people of Brussels are said to have tolerated for more than 300 years.

$21 \mathrm{~S} 21(1)(f)$.

22 The Commission of Enquiry in Regard to Undesirable Publications (also known as the Cronjé Commission).

23 Merrettt Culture of Censorship 35. 
statutory control of court reporting. ${ }^{24}$ The Commission's report also supported prior censorship in proposing that periodicals be registered, scrutinised before distribution and prohibited if necessary. While newspapers were exempted from these suggestions, their definition would be up to government. ${ }^{25}$

These proposals were incorporated in the Publications and Entertainments Bill, read for the first time in 1960, but, faced with strong protests, dropped. It was abandoned in favour of a Press Code and reintroduced, with amendments excluding the press, by the enactment of the Publications and Entertainment Act 26 of $1963 .^{26}$ The Act established the Publications Control Board, consisting of nine members, and introduced a system of control over "undesirable" publications, objects, films and public entertainment. ${ }^{27}$

Apart from amendments mainly concerned with bringing publications within the scope of censorship laws, no new legislation was introduced until the enactment of the Publications Act 42 of $1974^{28}$ which replaced the Publications Control Board with a Directorate of Publications. Under section 47 of the act, the category of "undesirable" films, publications, objects or public

Merrett Culture of Censorship 35.

Merrett Culture of Censorship 36.

Merrett Culture of Censorship 60.

27 Merrett Culture of Censorship 60. Under the act, the import of publications costing less than $50^{\mathrm{C}}$ was prohibited, apparently in an attempt to curtail pornographic publications. $\mathrm{S}$ $6(1)(c)$ of this Act described indecency and obscenity as: "[S]exual intercourse, prostitution, promiscuity, white-slavery, licentiousness, lust, passionate love scenes, homosexuality, sexual assault, rape, sodomy, masochism, sadism, sexual bestiality, abortion, change of sex, night life, physical poses, nudity, scant or inadequate dress, divorce, marital infidelity, adultery, illegitimacy, human or social deviation or degeneracy, or any other similar related phenomenon". In interpreting these concepts, the court in $S v$ $R 1964$ (1) SA 394 (T) at 395A-B found that the human body, if exposed, could by no means be called indecent. The circumstances and manner in which the body was exposed, had to be taken into consideration. If, however, there was anything suggestive in a posed photograph or if it showed a depiction of sexual intercourse or sexual solicitation, it could be concluded that the intention was to produce an indecent picture. In the matter of Republican Publications (Edms) Bpk v Raad van Beheer oor Publikasies 1973 (4) SA 549 (D) the court set aside the prohibition of the publication of a photographic article about a stripdancer. The woman's private parts were not visible in the photographs and only a small part of her breasts were shown. As the court found that neither young schoolboys would be sexually aroused, nor would young girls be persuaded to join the world of stripdancing, the article was not per se immoral or undesirable.

28 Once described by Nobel laureate, Nadine Gordimer, as the "octopus of thought surveillance." Merrett Culture of Censorship 79. 
entertainments now covered a much broader category of material, such as items which were:

- indecent or obscene or offensive to public morals;

- blasphemous or offensive to the religious convictions or feelings of any section of the inhabitants of the Republic;

- dangerous by bringing any section of the inhabitants of the Republic into ridicule or contempt;

- harmful to the relations between any sections of the inhabitants of the Republic; or

- prejudicial to the safety of the State, the general welfare or the peace and good order.

Following a long and bitter struggle against apartheid, the first democratically elected government of South Africa came into power in 1994. Just as previous successive governments had ensured that all laws dealing with films and publications reflected the aspirations of an apartheid-State, the new democratic Government immediately initiated a process to ensure that all laws henceforth would reflect - in form, substance and spirit - the values entrenched by the Constitution. ${ }^{29}$ Consequently, the Constitutional Court, in the matter of Case $v$ Minister of Safety and Security; Curtis $v$ Minister of Safety and Security, ${ }^{30}$ had to pronounce on the constitutionality of section 2(1) of the Indecent or Obscene Photographic Materials Act, ${ }^{31}$ paying particular attention to the right to privacy and the limitation thereof in context of the prohibition of possession of pornography and indeed found the provision to be inconsistent with the Constitution. $^{32}$ Some members of the Bench, however, acknowledged the

29 At the time the Interim Constitution (Act 200 of 1993), followed by the Constitution of the Republic of South Africa, 1996.

30 Case v Minister of Safety and Security; Curtis v Minister of Safety and Security 1996 (3) SA 617 (CC).

31 Indecent or Obscene Photographic Materials Act 37 of 1967. The section provided as follows: "Any person who has in his possession any indecent or obscene photographic matter shall be guilty of an offence and liable on conviction to a fine not exceeding one thousand rand or imprisonment for a period not exceeding one year or to both such fine and such imprisonment."

32 The Constitution of the Republic of South Africa Act 200 of 1993. Didcott $\mathrm{j}$ inter alia found that the relevant section was an infringement on a person's right to privacy, stating at par 
possibility of a reasonable limitation on certain freedoms in certain circumstances and distinguished this limitation from the restraints enforced by previous pieces of legislation:

My understanding is that this statement is subject to the qualification that the right referred to, as is the case with other chap 3 rights, is not necessarily exempt from limitation. That the limitation may extend to possession even in the privacy of one's home in certain circumstances is a possibility acknowledged by Didcott $\mathrm{J}$ in para [93]. The precise circumstances are not a matter we are called upon to delineate here and I agree that it is wise to refrain from attempting to do so in this matter. What is clear is that an intrusion into such privacy cannot, as was the case in the past, be permissible unless it can be adequately justified on the basis of section 33(1) of the Constitution. $^{33}$

Madala $\mathrm{j}$ furthermore aptly summarised the purpose of the (still to be enacted) Films and Publications Act in the following words:

While I agree that one's right to privacy should be respected, this, in my view, does not mean that all pornographic or similar material warrants protection under that right or even under the wing of free expression. There seems to be considerable consensus, both here and abroad, that some forms of pornography and obscene matter should not enjoy constitutional protection. In my view, children should not be exposed to or participate in the production of pornography, and that, therefore, possession by them and exposure to pornographic material should be prohibited. However, possession by adults, in the privacy of their homes for personal viewing of sexually explicit erotica, portraying nudity, sexual interaction between consenting adults, without aggression, force, violence or

[91] that: "What erotic material I may choose to keep within the privacy of my home, and only for my personal use there, is nobody's business but mine. It is certainly not the business of society or the State. Any ban imposed on my possession of such material for that solitary purpose invades the personal privacy which s 13 of the interim Constitution (Act 200 of 1993) guarantees that I shall enjoy."

33 Per Langa j (as he then was) at par [99]. Mokgoro j also dissented from Didcott j's view by expressing her opinion on the matter at par [65] of the judgment: "I must agree with his conclusion that the 1967 Act unreasonably and unjustifiably infringes the constitutional right to privacy. I would, however, respectfully part company from Justice Didcott to the extent that any part of his opinion might be read to suggest that it is not in any circumstances the business of the State to regulate the kinds of expressive material an individual may consume in the privacy of her or his own home. It may be so that, as in England, a 'South African's home is his (or her) castle'. But I would hesitate to endorse the view that its walls are impregnable to the reach of governmental regulation affecting expressive materials. I therefore associate myself with the caveat expressed by Justices Langa and Madala regarding Justice Didcott's opinion." 
abuse, may not be prohibited, for the benefit of those who derive pleasure in viewing such material. ${ }^{34}$

The court found that the provision of section 2(1) was unjustly overbroad in that it introduced vague concepts such as licentiousness and lust, discriminated against same-sex activities and made no distinction between regulating what is offensive and prohibiting what is harmful. ${ }^{35}$

\section{$3 \quad$ The Films and Publications Act 65 of 1996}

The Films and Publications Act came into operation on 16 January 1998. It introduced a dramatic shift from censorship to classification: whereas censorship involves the regulation of what others may see or read, classification involves the regulation of material by means of the imposition of age restrictions and the provision of information on the basis of which choices about what to see or read may be made. Adult South Africans would no longer be told what they may see or read, or what they may allow their children to see or read by "faceless bureaucrats in grey suits". ${ }^{36}$ The proposed amendments were welcomed by both the government and political parties and unanimously adopted by all members of Parliament. ${ }^{37}$

The Act seeks to regulate the distribution, exhibition and possession of films, interactive computer games and publications with due regard to the protection of children from sexual exploitation and degradation, and from exposure to potentially disturbing, harmful and age-inappropriate materials. ${ }^{38}$ It receives its

34 Case n 30 supra at par [105], emphasis added.

35 Sachs $\mathrm{j}$ at par [108] came to the conclusion that this obscurity could lead to the prohibition of possibly three-quarters of coffee-table art books and even many tastefully illustrated copies of the Bible or Shakespeare.

36 Hansard 19 March 1999 Col 2887-2888. During the Parliamentary Debate on the amendments to the Act, the Deputy Minister of Home Affairs emphasised that the Act was not one of censorship, but rather one that intends to protect children from harm.

37 Hansard 19 March 1999 Col 2887-2899.

38 See also s 2 of the Act which states that the objects of the Act shall be to "(a) regulate the creation, production, possession and distribution of certain publications and certain films by means of classification, the imposition of age restrictions and the giving of consumer advice, due regard being had in particular to the protection of children against sexual 
mandate from section 28 of the Constitution in that children should be protected form abuse, degradation, and maltreatment. It consequently intends to strike a reasonable balance between the right of a child to be protected against exploitation and harm and other fundamental freedoms and rights, such as the freedom of expression, enshrined in the Constitution. The Act is distinguishable from previous pieces of censorship legislation in that it limits its application to issues of sexuality, violence and religion and applies, in so far as children are concerned, generally to disturbing or harmful materials. In so far as sexuality and violence are concerned, the basis of proscription, in the main, is abuse or harm. ${ }^{39}$

exploitation or degradation in publications, films and on the Internet; and (b) make the exploitative use of children in pornographic publications, films or on the Internet, punishable."

39 The constitutionality of certain provisions of the Act has been tested in the matter of De Reuck v Director of Public Prosecutions, Witwatersrand Local Division 2004 (1) SA 406 (CC) (2003 (12) BCLR 1333). (See also the High Court decisions reported at 2002 (6) SA 370 (W) and 2003 (3) SA 389 (W) (2003 (1) SACR 448; 2002 (12) BCLR 1285).) The applicant in this case, a film producer, had unsuccessfully challenged the constitutionality of certain provisions of the Act in the High Court and consequently appealed directly to the Constitutional Court. He contended that the provisions of s 27(1) of the Act (which prohibits the creation, production, importation or possession of child pornography), read with the definition of child pornography in s 1 of the Act, limited the right to privacy, freedom of expression and equality. He further averred that the limitation was not justifiable as it was overbroad and vague. The court found that the State had established three legitimate objectives which the limitation imposed by s 27 of the Act aimed to serve, namely, protecting the dignity of children, stamping out the market for photographs made by abusing children and preventing a reasonable risk that images will be used to harm children. These important legislative purposes, together with the legislative safeguards provided, as well as the difficulty of legislating in this area at all, outweighed the relatively narrow infringement of expression. With regard to the argument that the limitation imposed by $s 27$ was overbroad, the court considered the exemption procedure set out in s 22 of the Act. S 22 permits a person who wishes to possess or otherwise deal with child pornography in breach of s 27 to apply to do so to an executive committee of the Board. Such exemption may be granted should the Board have "good reason to believe that bona fide purposes will be served by such an exemption." As the Act thus did allow for researchers of child pornography to be exempted from prosecution, the court concluded that the nature and extent of the limitation was not severe. It was thus reasonable and justifiable for the rights of researchers and film-makers in relation to possession and importation of child pornography to be limited by s 27(1), read with s 22 of the Act. The court furthermore found that $s$ 27(1) constitutes a reasonable and justifiable limitation on the right to freedom of expression and that, since many of the resultant acts of abuse against children, such as downloading child pornography from the Internet, take place in private, and the reasonable risk of harm to children is thus likely to materialise in private, some intrusion by the law into the private domain was justified. The limitation of the right to privacy was consequently also justifiable and the applicant's appeal was dismissed. 


\section{The current classification process in South Africa}

Whereas the Films and Publications Act, and consequently the Film and Publication Board, seeks to regulate the distribution and exhibition of films, interactive video games and certain publications, the Broadcasting Complaints Commission of South Africa (the BCCSA) seeks to ensure adherence to its Code from the members of the National Association of Broadcasters in South Africa. ${ }^{40}$ The Press Ombudsman, the self-regulatory body of the South African print media, in turn provides an independent complaint mechanism which mediates, settles and adjudicates complaints in accordance with a Code and Procedure accepted by the founding bodies. ${ }^{41}$

The distribution, exhibition and possession of films, interactive games and publications are regulated by means of classification, the imposition of age restrictions and the giving of consumer information about the content of films, games and publications, thus equipping parents and care-givers to make informed viewing, gaming and reading choices for the children in their care. In terms of section 31(3) of the Films and Publications Act, the Board is required to publish guidelines to be used to determine what is disturbing, harmful and threatening to children and to advise the viewing public about such images and scenes. During the classification process the film, interactive game or publication is examined against this set of guidelines by a committee consisting of at least three examiners (appointed for their experience, knowledge and qualifications in disciplines relevant to films, games and publications).

40 More information on the BCCSA is available on their website at http://www.bccsa.co.za.

41 More information on the Press Ombudsman is available on their website at http://www.ombudsman.org.za. The Advertising Standards Authority of South Africa (ASA), another self-regulatory body set up and paid for by the marketing communication industry, also has a Code of Advertising Practice which aims to "protect the consumer, and to ensure professionalism among advertisers". More information on the ASA is available at their website at http://www.asasa.org.za. 
Films are classified into two categories, namely restricted $(X 18)^{42}$ - which may only be distributed to adults by the holders of licences to conduct business of adult premises and only from within such licensed premises - and unrestricted - which include age-restricted films but which may be distributed by any distributor registered with the Board as such. Films which are classified XX, judged within context to contain scenes of:

i) bestiality, incest or rape;

ii) explicit sexual conduct which violates or shows disrespect for the right to human dignity of any person or which degrades a person or which constitutes incitement to cause harm;

iii) the explicit infliction of extreme violence or the explicit effects of extreme violence which constitutes incitement to cause harm; ${ }^{43}$

iv) or advocates hatred that is based on race, ethnicity, gender or religion and constitutes incitement to cause harm ${ }^{44}$

may not be distributed or broadcasted. ${ }^{45}$ Furthermore, in terms of section 29(2), a person shall be guilty of an offence if he/she -

...knowingly broadcasts, exhibits in public or distributes a film which, judged within context -

(a) amounts to propaganda for war;

(b) incites to imminent violence; or

(c) advocates hatred that is based on race, ethnicity, gender or religion, and which constitutes incitement to cause harm. ${ }^{46}$

42 These are films which, in terms of sch 7, contain "a scene or scenes, simulated or real, judged within context, of explicit sexual conduct which, in the case of sexual intercourse, includes an explicit visual presentation of genitals".

43 In terms of sch 6 of the Act. In terms of sch 9 the XX or X18 classification shall not be applicable to a bona fide scientific, documentary, dramatic or an artistic film or any part of a film which, judged within context, is of such a nature.

44 In terms of sch 10(1) of the Act. In terms of sch 10(2) a film shall not be classified as XX should it be "(a) a bona fide scientific, documentary, artistic, dramatic, literary or religious film or publication, or any part thereof which, judged within context, is of such a nature; (b) a film or publication which amounts to a bona fide discussion, argument or opinion on a matter pertaining to religion, belief or conscience; or (c) a film or publication which amounts to a bona fide discussion, argument or opinion on a matter of public interest".

45 In terms of $s$ 26(1)(aA) of the Act. Films or publications deemed to contain scenes or descriptions of child pornography are not classified but merely classed as "refused to classify" and referred to the South African Police Service.

46 Compare to s 16(2) of the Constitution which also does not extend the right of freedom of expression to material which contain the above-mentioned. Also see s 16.3 of Appendix II of the Code of the BCCSA. 
A person who is or is deemed to be the holder of a broadcasting licence in terms of the Independent Broadcasting Authority Act ${ }^{47}$ and who is subject to section 56(1) or (2) of that Act, shall be exempt from the duty to apply for a classification of a film and shall in relation to the exhibition of a film not be subject to any classification made by the Board or any condition imposed in relation to the exhibition of the film by the Board. ${ }^{48}$

Any person who intends to publish, distribute or exhibit in public any publication containing a visual presentation or description of:

i) explicit violent sexual conduct;

ii) bestiality, incest or rape;

iii) explicit sexual conduct which violates or shows disrespect for the right to human dignity of any person or which degrades a person or which constitutes incitement to cause harm; or

iv) the explicit infliction of or explicit effect of extreme violence which constitutes incitement to cause harm; ${ }^{49}$

v) it contains a visual presentation, simulated or real, of explicit sexual conduct which, in the case of sexual intercourse, includes an explicit visual presentation of genitals; ${ }^{50}$

vi) it describes predominantly and explicitly any or all of the above-mentioned acts; ${ }^{51}$

must submit such publication for classification prior to its distribution or exhibition. ${ }^{52}$ As in the case of films, a person shall be guilty of an offence if he/she -

47 Independent Broadcasting Authority Act 153 of 1993.

48 S 23(3) of the Films and Publications Act.

49 Sch 1(b)-(e). Such a publication will then be classified as ' $X X$ ' and may not be distributed or advertised for distribution. It is submitted that practically speaking, the only reason why any person who intends to publish, distribute or exhibit such material, will submit it for classification, is that it may fall into the exemption clause provided by sch 10 . In terms of sch 10(2) a publication shall not be classified as XX should it be "(a) a bona fide scientific, documentary, artistic, dramatic, literary or religious film or publication, or any part thereof which, judged within context, is of such a nature; (b) a film or publication which amounts to a bona fide discussion, argument or opinion on a matter pertaining to religion, belief or conscience; or (c) a film or publication which amounts to a bona fide discussion, argument or opinion on a matter of public interest".

50 Such a publication shall then be classified as 'X18' in terms of $s 17(1)(a)(i)(b b)$ and may only be distributed to adults by the holders of licences to conduct business of adult premises and only from within such licensed premises. Once again the XX or X18 classification shall not be applied in respect of a bona fide scientific, documentary, literary or an artistic publication, or any part of a publication which, judged within context, is of such a nature (in terms of sch 5).

51 Sch 2. 
...knowingly broadcasts or distributes a publication which, judged within context -

(a) amounts to propaganda for war;

(b) incites to imminent violence; or

(c) advocates hatred that is based on race, ethnicity, gender or religion, and which constitutes incitement to cause harm."

The Board does not, however, as is the case with films, classify all publications, but only classifies publications which do not fall into the XX or X18 category, upon the receipt of a complaint by any member of the public. ${ }^{54}$ Should the classification committee deem it necessary to protect children from disturbing or harmful materials contained in the publication, it shall determine that the publication only be distributed to persons of, or above, a specified age and may impose the condition that it only be distributed in a sealed and opaque wrapper which bears a distinct notice of the specified age restriction. ${ }^{55}$

The Act does not at present apply to any newspapers published, or posters of a newspaper issued as an advertisement of any newspaper, by a publisher who is a member of the Newspaper Press Union of South Africa. ${ }^{56}$

$52 \mathrm{~S} 17(4)$

53 S 29(1) of the Act. Compare to s 16(2) of the Constitution which also does not extend the right of freedom of expression to material which contain the above-mentioned.

$54 \mathrm{~S} 16$.

$55 \mathrm{~S} 17(1)(\mathrm{a})(\mathrm{ii})$ and sch 3 of the Act.

56 S 22(3). 
5 The implications of the Films and Publications Amendment Bill, B27-2006 ${ }^{57}$

The most controversial provisions of the Amendment Bill is that of clauses 13 and 14 which intends to replace section 16 and repeal section 17 of the current Act. Section 16(1) of the Act will in future still provide for the application by any member of the public requesting that a publication be classified in terms of this section. Section 16(2), shall, however, stipulate that -

[a]ny person who creates, produces, publishes or advertises for distribution or exhibition in the Republic any publication that contains visual presentations, descriptions or representation of or amounting to -

(a) sexual conduct;

(b) propaganda for war;

(c) incitement to imminent violence;

(d) the advocacy of hatred based on any identifiable group characteristic,

shall submit in the prescribed manner such publication for examination and classification to the classification office before such publication is distributed, exhibited, offered or advertised for distribution or exhibition.

Such a publication so submitted shall then be classified by a classification committee, consisting of at least three classifiers. ${ }^{58}$ Any publication referred to a classification committee may be classified:

57 The Bill also intends to amend the structure and composition of the Board, as well as the Review Board (see $\mathrm{cl}$ 2-12 of the Bill), but these amendments will not be discussed for the purposes of this article. It should also be noted that the Internet Service Provider Association of South Africa (ISPA) also has reacted to the amendments, commenting that the provisions, and in particular S 24C, targets the "wrong entities", and is not technologyneutral. S 24C would potentially make ISPs responsible for Internet chat services which they do not actually run as ISPS rarely provide content themselves and rather facilitate connectivity. ISPA is therefore concerned about the requirement that "content should be submitted for classification prior to publishing it on the internet." The Bill also places an obligation on ISPs to provide "all their subscribers" with filtering software. As child protection software is "somewhat inappropriate for the corporate market", ISPA suggests that the obligation should rather be to provide customers with the ability to obtain the software. ISPA is, however, committed to discussion and consultation regarding all the policy issues surrounding the proposed amendments. See Booth 2006 http://www.ispa.co.za 9 Nov. S 16(3). 
(a) as a 'refused classification' if the publication contains [a] visual presentation, description or representation of -

(i) child abuse, ${ }^{59}$ propaganda for war or incitement to imminent violence; or

(ii) the advocacy of hatred based on any identifiable group characteristic, unless, judged within context, the publication is a bona fide documentary or is a publication of scientific and literary merit on a matter of public interest. $^{60}$

It may also be classified as $\mathrm{X} \mathrm{X}^{61}$ or $\mathrm{X} 18^{62}$ unless -

...judged within context, the publication is a bona fide documentary or is a publication of scientific, literary or artistic merit, in which event the publication shall be classified with reference to the guidelines relating to the protection of children from exposure to disturbing, harmful and age-inappropriate materials.

As is presently the case under the Act, a classification committee furthermore also may impose certain appropriate age-restrictions and conditions it may deem necessary to protect children from disturbing or harmful materials contained in the publication. ${ }^{63}$

Another controversial aspect is that section 22(3) of the Act, which currently exempts newspapers published by a publisher who is a member of the Newspaper Press Union of South Africa, from the Act, will also be deleted by the proposed amendments. ${ }^{64}$ This will, practically speaking, mean that should any newspaper, magazine or any publisher in future intend to publish a

59 Child abuse is defined by s 1 of the Bill as "the use of a child in the creation, making or production of child pornography or child abuse images or for sexual exploitation and includes exhibiting or showing images of sexual conduct to a child or exposing or encouraging a child to witness sexual conduct".

$60 \mathrm{~S} 16(4)(a)$.

61 Should the publication in terms of $s$ 16(4)(b) contain "visual presentations or graphic descriptions or representations of - (i) explicit sexual conduct which violates or shows disrespect for the right to human dignity of any person; (ii) conduct or an act which is degrading of human beings; or (iii) conduct or an act which constitutes incitement to or encourages or promotes harmful behaviour".

62 Should the publication in terms of $s 16(4)(c)$ contain "visual presentations or graphic descriptions or representations of - (i) explicit sexual conduct; (ii) the explicit infliction of sexual or domestic violence, or (iii) the explicit effects of extreme violence".

$63 \mathrm{~S} 17(1)(\mathrm{a})(\mathrm{ii})$ and sch 3 of the Act, see above.

$64 \mathrm{Cl} 20(c)$ of the Bill. 
publication ${ }^{65}$ which contains visual presentations, descriptions or representation of or amounting to sexual conduct, that is:

(i) male genitals in a state of arousal or stimulation;

(ii) the undue display of genitals or of the anal region;

(iii) masturbation;

(iv) bestiality;

(v) sexual intercourse, whether real or simulated, including anal sexual intercourse;

(vi) sexual contact involving the direct or indirect fondling or touching of the intimate parts of a body, including the breasts, with or without any object;

(vii) the penetration of a vagina or anus with any object;

(viii) oral genital contact; or

(ix) oral anal contact. ${ }^{66}$

Such publication should first be submitted to the Board for classification.

Jane Duncan, the Executive Director of the Freedom of Expression Institute, has in reaction commented that it appears that the provision would "consider all expressions of a sexual nature as suspect, requiring state scrutiny" and that the Bill -

...harks back to the Publications Act of 1974, which banned publications if they were considered to be indecent, obscene or offensive to public morals. ${ }^{67}$

To answer her question as to "[w]hat is meant by 'sexual conduct"', the Act is, as can be seen from the above definition, rather clear. The current definition by the Act of "sexual conduct", which has not been altered by the amendments, is quite plain on what it considers as such and thus it cannot be said that the

65 Currently defined under the Act as “(a) any newspaper, book, periodical, pamphlet, poster or other printed matter; (b) any writing or typescript which has in any manner been duplicated; (c) any drawing, picture, illustration or painting; (d) any print, photograph, engraving or lithograph; (e) any record, magnetic tape, soundtrack, except a soundtrack associated with a film, or any other object in or on which sound has been recorded for reproduction; ( $f$ ) computer software which is not a film; $(g)$ the cover or packaging of a film; (h) any figure, carving, statue or model; and (i) any message or communication, including a visual presentation, placed on any distributed network including, but not confined to, the Internet".

66 In terms of s 1 of the current Act.

67 Duncan 2006 Business Day http://www.businessday.co.za/ 16 Aug. 
amendments are a step backwards towards vague and non-descriptive terms such as indecency and obscenity. ${ }^{68}$ Her further concern of whether or not it would mean that should an agency produce an advertisement of two people kissing, they would need to submit this for classification, as a result undoubtedly can be answered in the negative.

Rather, the question should be asked as to why a newspaper would need to publish any article describing any of the above acts defined as sexual conduct and should the need indeed arise, why newspapers in particular could be exempted from the classification process, bearing in mind that the Act presently requires all publications, barring newspapers, containing visual presentations of explicit sexual conduct "which, in the case of sexual intercourse, includes an explicit visual presentation of genitals" to be submitted for publication. Newspaper classified advertisements are often -

...packed with the most descriptive, lurid, suggestive and blatant touting for prostitution imaginable. All of which leaves absolutely nothing to the imagination. ${ }^{69}$

Tabloid publications such as "Die Son/The Sun" and "The Daily Voice" are known for their detailed and often sordid descriptions of sexual activities and the growing demand for sex as a commodity is only reflected by these publications. $^{70}$ As children have unrestricted access to this material, at affordable prices and often en route to school, the question begs to be answered as to why the protection of children should be less important than the

68 It should be noted that The Preamble of the Press Code of Professional Practice actually rather vaguely states that "[r]eports, photographs or sketches relative to matters involving indecency or obscenity shall be presented with due sensitivity towards the prevailing moral climate".

69 Moerdyk 2006 http://www.bizcommunity.com/ 20 Apr.

70 In response to the reaction by the media to the amendments, Mr I Chetty, Head of Legal Services of the Film and Publication Board wrote: "The response of some sections of the media to the proposed amendment to bring newspapers and broadcasters within the scope of the Films and Publications Act is not unrelated to the preservation of the "wealthgenerating' culture of newspapers and broadcasters. Newspaper publishers and broadcasters will not welcome anything that might limit their capacity to generate wealth from their businesses. But, of course, their objections would have to be couched in 'freedom of expression' terms! Newspaper publishers and broadcasters should accept that choices in the interests of the protection of children have to be made", Chetty "Memorandum". 
right of the press to publish descriptions of sexual conduct. The State has a duty to protect the dignity of children in the same manner as it has to protect the dignity and freedoms of all other persons in this country. How can the government's attempts at protecting children from, what is in essence a form of child abuse $^{71}$ and a denial of their dignity, ${ }^{72}$ then be classed as censorship, all in the name of freedom of speech ${ }^{73}$ Why should the media, and in particular the printed press, be excluded from the obligation to protect children from harmful and age-inappropriate material? Section 22(3) provides, in any event, that only newspapers published by a publisher who is a member of the Newspaper Press Union of South Africa, a Union which no longer exists, are exempted. ${ }^{74}$ This would, therefore, mean also that such newspapers also are not subject to the anti-child pornography provisions of the Act, such as section 27 prohibiting the creation, production, importation or possession of child pornography. Should we allow this exemption to continue, the State indeed will be failing its children and neglecting adherence to their plight, made in a statement released by the Deputy-Minister of Home Affairs at the launch of the Child Pornography Hotline in 2004:

We, the children of South Africa, in thanking Government for this important initiative, expect that all necessary measures will be taken to stop our abuse and exploitation and assure us of that childhood guaranteed to us by the Constitution.

71 See the proposed definition of 'child abuse' in the Bill as including "exhibiting or showing images of sexual conduct to a child or exposing or encouraging a child to witness sexual conduct".

72 See eg the comments made by the magistrate in the so-called "Santa Claus" case, where, in sentencing convicted paedophile, James McNeil, the magistrate described the pornographic images which police had found in McNeil's possession as "repulsive and invasive of the dignity of the child". Schroeder 2003 http://www.iol.co.za/ 5 Dec.

73 Compare further the remarks of Madala j in Case n 30 supra at par [105] that "children should not be exposed to or participate in the production of pornography, and that, therefore, possession by them and exposure to pornographic material should be prohibited". The Film and Publication Board has also recently released a report on internet usage and the exposure of pornography to learners in South African schools, see Chetty and Basson 2007 http://www.fpb.gov.za/ 20 Apr, concluding that it is common for South African children to come into contact with pornography, and that in most cases this occurs within their immediate environment. A multi-stakeholder approach between parents, caregivers, teachers and other stakeholders is also proposed.

74 Thus it also can be argued that the "blanket exemption" no longer exists. 
More criticism was raised against the provisions prescribing pre-publication submission of material containing "propaganda for war" or "incitement to imminent violence" and the fact that it "leaves out artistic merit as a ground for exemption". ${ }^{75}$ These provisions have also been described as containing "hazy and ill-defined concepts" which will -

...not only cause confusion among media organisations, [but] ... may also induce the media to avoid these subjects in order to escape prosecution. $^{76}$

As the Constitution clearly does not extend the right to freedom of expression to this type of material ${ }^{77}$ and it is currently an offence under the Act to exhibit or distribute a film ${ }^{78}$ or broadcast or distribute a publication containing such, ${ }^{79}$ it is unclear as to why this objection is raised.

It is, however, submitted that the criticism against the "unconstitutional reformulation of the hate speech" ${ }^{80}$ is justified as the Constitution only prohibits

...advocacy of hatred that is based on race, ethnicity, gender or religion, and that constitutes incitement to cause harm ${ }^{81}$

and does not proscribe "the advocacy of hatred based on any identifiable group characteristic" which the Bill seeks to do in section 16(2)(d) and section 16(4)(a)(ii). ${ }^{82}$ It is submitted that the provision broadens the scope of grounds

75 Duncan 2006 Business Day http://www.businessday.co.za/ 16 Aug.

76 IPI 2006 http://www.freemedia.at/ 11 Sep, letter to President Thabo Mbeki.

77 See s 16(2) of the Constitution discussed above.

78 See $\mathrm{s} 29(2)$ of the Act discussed above.

79 See s 29(1) of the Act discussed above. The Code of the BCCSA at par 16.3 also prohibits licensees from broadcasting such material. The Press Code of Professional Practice furthermore at 2.3 stipulates that " $[\mathrm{t}]$ he press has the right and indeed the duty to report and comment on all matters of public interest. This right and duty must, however, be balanced against the obligation not to promote racial hatred or discord in such a way as to create the likelihood of imminent violence."

80 Duncan 2006 Business Day http://www.businessday.co.za/ 16 Aug; see also Smuts 2006 Sunday Times 36; Boyle 2006 Sunday Times 2; and the joint statement by SANEF 2006 http://www.sanef.org.za/ 12 Nov.

$81 \mathrm{~S} 16(2)(c)$.

82 See also s 18(3)(a)(ii) which will prohibit films judged to contain the above-mentioned material. Compare the Code of the BCCSA which proscribes the broadcasting of material which, "judged within context, sanctions, promotes or glamorizes violence based on race, 
beyond the categories of expression listed by section 16(2) of the Constitution. As the Constitutional Court per Langa dcj (as he then was) has already affirmed that -

[w]here the State extends the scope of regulation beyond expression envisaged in section 16(2), it encroaches on the terrain of protected expression and can do so only if such regulation meets the justification criteria in section $36(1)$ of the Constitution, ${ }^{83} \ldots$

it can be predicted fairly safely that this provision of the Bill will not pass any constitutional scrutiny. In Islamic Unity Convention v Independent Broadcasting Authority $^{84}$ a similar provision from the Code of Conduct for Broadcasting Services, which provided that "(b)roadcasting licensees shall ... not broadcast any material which is ... likely to prejudice ... relations between sections of the population", was found to be -

...so widely phrased and so far-reaching that it would be difficult to know beforehand what is really prohibited or permitted. ${ }^{85}$

The court also placed emphasis on the fact that the prohibition did not require the material to have any potential to cause harm ${ }^{86}$ and that it had not been shown that -

...the very real need to protect dignity, equality and the development of national unity could not be served adequately by the enactment of a provision which [was] appropriately tailored and more narrowly focused. ${ }^{87}$

The relevant portion of the clause from the Code therefore was found impermissibly to limit the right to freedom of expression and was accordingly

national or ethnic origin, colour, religion, gender, sexual orientation, age, or mental or physical disability".

83 Islamic Unity Convention v Independent Broadcasting Authority 2002 (4) SA 294 (CC) (2002 (5) BCLR 433).

84 Supra.

85 At par [44].

86 At par [35]. In Freedom Front $v$ South African Human Rights Commission 2003 (1) BCLR 1283 (SAHRC) the SAHRC held that "harm" could not be confined to physical harm but should be taken to include psychological and emotional harm.

87 At par [51]. 
unconstitutional. $^{88}$ As section $16(2)(d)$ of the Films and Publications Amendment Bill similarly does not require any incitement to cause harm and does not limit the scope to advocacy based on race, ethnicity, gender, or religion it is envisaged that this provision will be found to be unconstitutional. It is submitted that it too could be tailored appropriately and focussed more narrowly in order to achieve its purpose.

However, at this point it also has to be noted that the amendments, as they are drafted currently, will not prohibit the distribution and exhibition of publications or films containing descriptions or scenes of bestiality as schedules 1 and 6 of the current Act is repealed by clause 33 of the Bill. It is not clear whether this is a deliberate move to decriminalise the distribution and exhibition of bestiality or whether it is merely an oversight which occurred during the drafting process.

One last amendment to the Act which deserves to be considered is that of the amendment to chapter 5 of the Act, namely the right to appear before and to appeal to the Review Board and the Supreme Court. ${ }^{89}$ In terms of clause 17 of the Bill, section 19 of the Act will be deleted. This would mean that any person who has lodged a complaint with the Board that any publication be referred to a classification committee for a decision and classification or who applied for a classification of a film, or the reclassification of a film or publication, or for a permit, exemption or licence, loses the right -

...to appear in person before the executive committee, classification committee or Review Board, or to be represented or assisted by a legal practitioner or by any other person of his or her choice, to adduce oral or written evidence and, subject to a reasonable timelimit imposed by the chairperson concerned, to address that committee or board, in the language of his or her choice.

This right to appeal is, however, addressed by the proposed amendment to section 20 of the Act, which in future will provide for the right of such a person to -

88 At par [51].

89 Now the High Court of South Africa. 
...appeal such a decision or finding of the Board to the Appeal Board $^{90}$ in the prescribed manner.

Absent from this provision, however, is the right to be represented by a legal practitioner or any other person. The Appeal Board may, notwithstanding, still prescribe the manner in which an appeal shall be heard and may, therefore, allow such representation as section $20(2)$ (c) of the Act will not be amended. ${ }^{91}$

Section 21 of the Act, which currently provides for an appeal to the High Court will however, in terms of the amendments, be deleted. It should be borne in mind that under section 33 of the Constitution and section 6 of the Promotion of Administrative Justice Act 3 of 2000 judicial review will always be available as a remedy to a person who feels aggrieved by a decision taken by a State organ such as the Film and Publication Board. What is important though, is to realise that under this reviewing process, the High Court only will be able to review whether the procedures employed during the decision making process was correct. This means that the court's power to hear the merits of the case and thus to -

...confirm the decision appealed against or ... set that decision aside, and give such decision, make such classification and impose such conditions as should in its view have been given, made or imposed $^{92} \ldots$

will be removed and in future will rest with the Appeal Board. ${ }^{93}$ The High Court will only be able to direct the Board to give reasons (if reasons were not given) or set aside the decision and refer it back to the Board, with or without

90 Any reference to the "Review Board" is to be substituted with the "Appeal Board" — see cl 5,$6 ; 8$ and 34 of the Bill.

91 This section provides that "[t]he chairperson of the Review [Appeal] Board may determine the procedure to be followed." A proposed new s $5 \mathrm{~A}(b)$ also states that the "Appeal Board shall have such powers as are necessary to determine the procedures and forms for the submission of appeals and the procedures to be followed at the hearing of appeals submitted to it".

92 As is currently the case under s 21(3) of the Act.

93 Under s 20(5) a "decision of the [Appeal] Board shall for the purposes of [the] Act be deemed to be a decision of the Board" whereas a similar provision conferring this power to the court, namely s 21(4) will be deleted. 
directions, and only in exceptional circumstances be able to substitute or vary the original decision. ${ }^{94}$

\section{Conclusion}

The promulgation of the Films and Publications Act sent a very clear message that censorship would no longer be tolerated in the open and democratic society of a new South Africa. Adult members of this society have the freedom to choose what material they wish to see and read, within the boundaries set by the Constitution, and furthermore have the freedom to choose what their children may see or read, based on the information given by the Film and Publication Board. The language used in the Act also signifies an era where vague and overbroad terms such as 'indecency' and 'obscenity', employed by the previous censorship legislation, can no longer be used to describe matter which may be subject to certain restrictions. Clear definitions of what is regarded as 'sexual conduct' or 'child pornography' are given in line with the standard of transparent and unambiguous legislation set by the Constitution. The regulations promulgated under the Act, which are used to determine what is disturbing, harmful and threatening to children, are revised on a yearly basis. These regulations are, furthermore, open to public scrutiny as members of the public are invited to comment on the amendment thereof or to complain about the age restrictions imposed on films, interactive computer games and publications.

The amendments to the Act (with the exception of the proposed new section 16(2)(d), section 16(4)(a)(ii) and section 18(3)(a)(ii)) also are worded in such a manner that it seems clear that it intends to further the purpose of the Act. These amendments which, in line with the Constitutional Court decision of Case $v$ Minister of Safety and Security; Curtis $v$ Minister of Safety and Security ${ }^{95}$ seek to "protect children from potentially disturbing, harmful or age- 
inappropriate materials" are not "part of a new trend in the gradual erosion of the freedom of speech" but rather part of a movement towards the realisation that the protection of children against harm is the obligation of all members of society. There is absolutely no reason as to why newspapers or any other member of the print media should be excluded from this duty. Practically speaking, it also would not lead to the delay of the publication or broadcast of news reports or the censorship thereof as only material containing visual presentations, descriptions or representations of sexual conduct would need to be submitted for classification. Certain restrictions may then be imposed upon these publications as they are inappropriate and harmful to children, but it cannot be banned outright. It is submitted that any committed journalist would realise that the imposition of these possible restrictions, and not censorship, would thus only apply in extraordinary circumstances. Under the current Act, all other publications, including magazines such as FHM, Cosmopolitan or Men's Health, already have to submit material which contains visual presentations of explicit sexual conduct or genitals. ${ }^{96}$ As the Constitution already proscribes material containing propaganda for war or incitement to imminent violence, it is submitted that the proposed section 16(2)(b) and (c) will have very little practical effect. However, with regard to advocacy of hatred, this provision of the Bill will have to be amended to ensure it does fall within the categories of expression listed by section 16(2) of the Constitution. ${ }^{97}$

Government already has indicated that it is willing to meet and consult with all interested parties regarding the policy issues affected by the Bill and consequently has suspended the promulgation of the amendments until such process has taken place. One only can hope that all such organisations and stakeholders will be prepared to consider rationally all the possible permutations of the issues at hand. In the process the media will have to demonstrate a sense of commitment to achieving a balance between the exercise of freedom of expression and the protection of children. If not, the breaking news just may, in future, break us completely.

96 Under s 17(1)(a)(i)(bb) of the Act discussed above.

97 See discussion above. 


\section{Bibliography}

Boyle 2006 Sunday Times 21

Boyle B "Back to a muzzled media" 2006 Sunday Times 8 October

Chetty "Memorandum"

Chetty I "Memorandum" (Unpublished internal communication sent to members of the Film and Publication Board, December 2006)

Gigaba 2006 Sunday Times 36

Gigaba M "Freedom of expression is not absolute" 2006 Sunday Times 15 Oct

Merrett Culture of Censorship Merrett CE A Culture of Censorship: Secrecy and Intellectual Repression in South Africa (Phillip Cape Town 1994)

Smuts 2006 Sunday Times 36

Smuts D "Political correctness trumps free speech" 2006 Sunday Times 15

October

\section{Register of legislation}

Cape of Good Hope Obscene Publications Act 31 of 1892

Constitution of the Republic of South Africa 1996

Constitution of the Republic of South Africa Act 200 of 1993

Customs Act 10 of 1872

Customs Act 35 of 1944

Customs Consolidation and Shipping Act 13 of 1899

Customs Management Act 9 of 1913

Customs Management Ordinance 23 of 1902

Entertainments (Censorship) Act 28 of 1931

Films and Publications Act 65 of 1996

Films and Publications Amendment Bill B27 2006

Government Gazette no 29169 of 31 August 2006 
Indecent or Obscene Photographic Materials Act 37 of 1967

Independent Broadcasting Authority Act 153 of 1993

Publications Act 42 of 1974

Publications and Entertainment Act 26 of 1963

\section{Register of court cases}

Case and Another v Minister of Safety and Security and Others; Curtis v

Minister of Safety and Security and Others 1996 (3) SA 617 (CC) (1996 (1) SACR 587; 1996 (5) BCLR 609)

De Reuck v Director of Public Prosecutions, Witwatersrand Local Division, and Others 2004 (1) SA 406 (CC) (2003 (12) BCLR 1333)

Freedom Front $v$ South African Human Rights Commission 2003 (1) BCLR 1283 (SAHRC)

Islamic Unity Convention v Independent Broadcasting Authority 2002 (4) SA

294 (CC) (2002 (5) BCLR 433)

Khumalo v Holomisa 2002 (5) SA 401 (CC) (2002 (8) BCLR 771)

$R$ v Bungaroo (1904) 25 NLR 28

$R$ v Hardy (1905) 26 NLR 165

$R v$ Hicklin (1868) LR 3 QB 360

$R \vee$ Marais (1886) 6 SC 367

$R \vee W 1953$ (3) SA 52 (SWA)

Republican Publications (Edms) Bpk v Raad van Beheer oor Publikasies 1973 (4) SA 549 (D)

S v R 1964 (1) SA 394 (T)

South African National Defence Union v Minister of Defence and Another 1999

(4) SA 469 (CC) (1999 (6) BCLR 615)

\section{Register of Internet resources}

Booth 2006 http://www.ispa.co.za 9 Nov

Booth I 2006 ISPA welcomes film bill extension [Found on internet] http://www.ispa.org.za/news/press081106.shtml [Date of use 9 November] 
Chetty and Basson 2006 http://www.fpb.gov.za/ 20 Apr

Chetty I and Basson A 2006 FPB Report on Internet Usage and the Exposure of Pornography to Learners in South African Schools [Found on internet] http://www.fpb.gov.za/research/docs/report.pdf [Date of use 20 April 2007]

Duncan 2006 Business Day http://www.businessday.co.za/ 16 Aug Duncan J "Dragging us back to the nanny state" 2006 Business Day 15 Aug [Found on internet] http://www.businessday.co.za/PrintFriendly.aspx?ID=BD4A250220 [Date of use 16 August 2006]

Harber 2006 The Harbinger http://www.big.co.za/ 9 Nov Harber A "Please tell us this is a mistake" in The Harbinger 10 Aug 2006 [Found on internet] http://www.big.co.za/wordpress/2006/08/10/please-tellus-this-is-a-mistake [Date of use 9 November 2006]

IPI 2006 http://www.freemedia.at/ 11 Sep

International Press Institute 2006 IPI Urges South African Government to Amend Films and Publications Amendment Bill, 2006 [Found on internet] http://www.freemedia.at/cms/ipi/statements detail.html?ctxid+CH0055\&doc $\underline{\mathrm{id}+\mathrm{CMS}}$ [Date of use 11 September 2006]

Leon 2006 SA Today http://www.da.org.za/ 29 Aug

Leon T "Warning bells on free speech" SA Today 25 Aug 2006 [Found on internet]

http://www.da.org.za/da/Site/Eng/satoday/SAToday.asp?SATodaylD=197 [Date of use 29 August 2006]

Moerdyk 2006 http://www.bizcommunity.com/ 20 Apr Moerdyk C 2006 Real censorship threat to media [Found on internet] http://www.bizcommunity.com/Article/196/15/11265.html [Date of use 20 April 2007] 
Quintal 2006 Pretoria News http://www.iol.co.za/ 3 Nov

Quintal A "Government says it will not censor media" Pretoria News 225

Aug 2006 [Found on internet]

http://www.iol.co.za/general/news/newsprint.php?art id=vn2006082501051

$\underline{0657 C 183018}$ [Date of use 3 November 2006]

Quotations 2007 http://www.quotationspage.com/ $20 \mathrm{Apr}$

Quotations 2007 Soren Kierkegaard: 1813-1855 [Found on Internet]

http://www.quotationspage.com/quotes/Soren Kierkegaard/ [Date of use 20

April 2007]

SANEF 2006 http://www.sanef.org.za/ 12 Nov

SANEF 2006 Statement by SANEF / FXI / MISA-SA on Media Censorship

planned by Government [Found on internet]

http://www.sanef.org.za/press statements/919812.htm [Date of use 12

November 2006]

Schroeder 2003 http://www.iol.co.za/ 5 Dec

Schroeder F "Paedophile Santa goes to jail for 5 years" [Found on internet] http://www.iol.co.za/index.php?set id=1\&click id=15\&art id=vn200306250 43909300C647802 [Date of use 5 December 2006]

\section{List of URLS}

ASA $\quad$ http://www.asasa.org.za

BCCSA http://www.bccsa.co.za

Press Ombudsman http://www.ombudsman.org.za

\section{List of abbreviations}

ASA Advertising Standards Authority of South Africa

BCCSA Broadcasting Complaints Commission of South Africa

ch chapter(s)

$\mathrm{cl} \quad$ clause(s)

FPB Film and Publication Board 


$\begin{array}{ll}\text { FXI } & \text { Freedom of Expression Institute } \\ \text { ISP } & \text { Internet Service Provider(s) } \\ \text { ISPA } & \text { Internet Service Provider Association of South Africa } \\ \text { IPI } & \text { International Press Institute } \\ \text { MISA } & \text { Media Institute of Southern Africa } \\ \text { par } & \text { paragraph(s) } \\ \text { S } & \text { section(s) } \\ \text { SANEF } & \text { South African National Editors' Forum } \\ \text { Sch } & \text { schedule(s) } \\ \text { SAHRC } & \text { South African Human Rights Commission } \\ \text { URL } & \text { Uniform Resource Locator }\end{array}$

